\title{
Effect of dietary supplementation with butyrate and probiotic on the survival of Pacific white shrimp after challenge with Vibrio alginolyticus
}

\author{
Norha Constanza Bolívar Ramírez¹, Marysol Santos Rodrigues ${ }^{1}$, Ariane Martins Guimarães', \\ Cristhiane Guertler ${ }^{1}$, Juliana Ribeiro Rosa ${ }^{1}$, Walter Quadros Seiffert ${ }^{1}$, Edemar Roberto \\ Andreatta $^{1}$, Felipe do Nascimento Vieira ${ }^{{ }^{*}}$
}

${ }^{1}$ Universidade Federal de Santa Catarina, Departamento de Aquicultura, Florianópolis, SC, Brazil.

\begin{abstract}
This study evaluated the performance, immunology, and survival of the Pacific white shrimp Litopenaeus vannamei to experimental challenge to Vibrio alginolyticus based on the use of the probiotic Lactobacillus plantarum and the combined use of probiotic and butyrate. Four different diets resulted from the addition of additives: butyrate, probiotic, butyrate + probiotic, and control (no additives). The attractiveness of the diets was assessed by the percentage of positive choices and rejections, using a dual-choice Y-maze format aquarium. The shrimps were fed during four weeks and performance parameters, intestinal microbiota, and immunological parameters were all evaluated. Subsequently, the shrimps were challenged with $V$. alginolyticus and after $48 \mathrm{~h}$, survival and immunological parameters were evaluated. The results showed increased attractiveness and intake, but only with diets supplemented with sodium butyrate. However, other diets were not rejected. No difference in performance or immunological parameters was observed among the different diets. Also, among the treatments, no difference in Vibrio spp., or total heterotrophic bacteria counts, was found in the intestinal tract. However, the lactic acid bacteria count was higher in the intestinal tract of shrimps fed diets supplemented with probiotic. After bacterial challenge, shrimp fed all diets had a greater survival when compared with the control group. Lactobacillus plantarum and sodium butyrate increase the resistance of shrimp to infection with $V$. alginolyticus, but do so without affecting performance, immunological parameters, or Vibrio spp., and total heterotrophic bacteria counts in the intestinal tract.
\end{abstract}

Key Words: animal production, lactic acid, organic acids

\section{Introduction}

The Pacific white shrimp Litopenaeus vannamei is the most cultivated species at $73.2 \%$ of the total volume produced (FAO, 2012). However, shrimp production has been drastically reduced in some countries as a consequence of the emergence of several diseases associated with aquaculture (Lightner, 2011), including early mortality syndrome (EMS) caused by a strain of Vibrio parahaemolyticus, mostly in Asia and Latin America (Lightner et al., 2012; Tran et al., 2013). Infections caused by Vibrio are considered an important problem in shrimp

Received: July 5, 2016

Accepted: March 13, 2017

*Corresponding author: felipe.vieira@ufsc.br

http://dx.doi.org/10.1590/S1806-92902017000600001

How to cite: Bolívar Ramírez, N. C.; Rodrigues, M. S.; Guimarães, A. M.; Guertler, C.; Rosa, J. R.; Seiffert, W. Q.; Andreatta, E. R. and Vieira, F. N. 2017. Effect of dietary supplementation with butyrate and probiotic on the survival of Pacific white shrimp after challenge with Vibrio alginolyticus. Revista Brasileira de Zootecnia 46(6):471-477.

Copyright (C) 2017 Sociedade Brasileira de Zootecnia. This is an Open Access article distributed under the terms of the Creative Commons Attribution License (http://creativecommons.org/licenses/by/4.0/), which permits unrestricted use, distribution, and reproduction in any medium, provided the original work is properly cited. farming, causing symptoms such as anorexia, inactivity, low growth rate, muscular necrosis and, consequently, high mortality (Chiu et al., 2007; Lafferty et al., 2015).

As treatment against vibriosis, antibiotics have been commonly used; however, inappropriate or excessive use in aquaculture has led to the selection of resistant bacteria (Deifordt et al., 2011). In addition, the use of antibiotics in aquaculture can affect human health and the environment as a result of residue contamination (Costanzo et al., 2005). Thus, for a sustainable development of the aquaculture sector, it is necessary to take steps towards an alternative to replace the use of antibiotics.

As such alternative measures, probiotics and organic acids, as well as their salts, have been widely implemented in aquaculture to decrease outbreaks of bacterial diseases. Probiotics may be defined as "a live microbial feed supplement which beneficially affects the host animal by improving its intestinal microbial balance" (Gram et al., 1999). Lactic acid bacteria (LAB) are widely used as probiotics by their rapid reproduction, production of antimicrobial compounds, such as bacteriocins, hydrogen peroxide, organic acids, and lactic acid and the capacity to stimulate host immune response (Gatesoupe, 2008). 
Organic acids can also inhibit bacteria, mostly Gramnegative, reducing the $\mathrm{pH}$ environment and forming chelate complexes with such essential minerals as iron, thus limiting the growth of other microorganisms (Jones, 1998; Lückstädt, 2008). Many organic acids are also available in sodium, potassium, and calcium salts, having the advantages of being odorless and less corrosive. They are also easy to manipulate as a feed additive by their solidity and lack of volatility (Partanen and Mroz, 1999).

This study evaluated the performance, immunology, and survival of the Pacific white shrimp Litopenaeus vannamei to experimental challenge to Vibrio alginolyticus based on the use of the probiotic L. plantarum and the combined use of probiotic and butyrate.

\section{Material and Methods}

Lactobacillus plantarum was the bacterial strain used as the probiotic. It was isolated from adult shrimps of L. vannamei (Vieira et al., 2007) and maintained in the collection of microorganisms in Florianópolis, SC, Brazil $\left(27.5949^{\circ} \mathrm{S}, 48.5482^{\circ} \mathrm{W}\right)$. Sodium butyrate $\left(\mathrm{C}_{3} \mathrm{H}_{7} \mathrm{COONa}\right)$ was chosen as the organic salt by having presented the best results of in vitro inhibition against $V$. alginolyticus among eight different salts in previous tests.

Diets were prepared as shown in Table 1. Ingredients were ground and sieved $(500 \mu \mathrm{m})$. Subsequently, the microingredients were homogenized in a Y-mixer for $10 \mathrm{~min}$ and added to the macro-ingredients for homogenization in a food mixer for $10 \mathrm{~min}$. Soon afterwards, oils and soy lecithin were added, followed by $40 \%$ hot water $\left(40{ }^{\circ} \mathrm{C}\right)$. The resulting mixture was pelletized through a meat grinder and dried for approximately $18 \mathrm{~h}$ at $40^{\circ} \mathrm{C}$. The organic acid salts were added in the respective quantities to replace kaolin, which was used as a filler. Posteriorly, the probiotic was included in the diet by the inoculation of $10 \%$ of the lactic acid bacteria in the diet (Vieira et al., 2008).

Diets were divided as follows: butyrate, probiotic, butyrate + probiotic, and control (diet without additives). Two percent of the organic salt $(\mathrm{p} / \mathrm{p})$ and $100 \mathrm{~mL}$ of probiotic $\left(1 \times 10^{7} \mathrm{CFU} \mathrm{mL}^{-1}\right)$ per kilogram were added to the diet according to the methodology described by Vieira et al. (2008).

The proximate composition of the diets (Table 2) was performed according to the methodology described by the Association of Official Analytical Chemists (AOAC, 2005). Dry matter (DM) was calculated by gravimetric analysis after drying in an oven at $100{ }^{\circ} \mathrm{C}$ for $24 \mathrm{~h}$. The ash content was determined gravimetrically by burning in a muffle furnace at $550{ }^{\circ} \mathrm{C}$ for $6 \mathrm{~h}(942.05$ in the AOAC, 2005). The method of Kjeldahl (2001.11 in the AOAC, 2005) was used to determine the crude protein content. Crude fiber and ether extract with acid hydrolysis were analyzed by methods 978.10 and 2003.05, respectively (AOAC, 2005).

Feed attractiveness was evaluated using the methodology described by Nunes et al. (2006) through the Y-maze aquarium. A total of 60 shrimps weighing $4.1 \pm 1.3 \mathrm{~g}$ were fasted for $24 \mathrm{~h}$ to stimulate the feeding response before each test. Before every session, the water of each aquarium was changed to avoid the influence of nutrients or the possible presence of remaining feed.

For each observation, two diets were compared. These were offered separately in similar amounts $(2 \mathrm{~g})$ and placed individually in the perimeter of one of the Y-maze apparatus arms. Prior to behavioral evaluation, the shrimps were stocked in the acclimation chamber and allowed to acclimate to the Y-maze system for $10 \mathrm{~min}$. For each experimental diet, one different specimen of L. vannamei was used at a time. In the event that feed was not detected within a 7-min time limit, the observation was interrupted

Table 1 - Composition of the experimental diets (control and butyrate) used in the growth of Litopenaeus vannamei in a clearwater system

\begin{tabular}{lcc}
\hline Ingredient $^{1}$ & $\begin{array}{c}\text { Control } \\
\text { g. } \mathrm{kg}^{-1}\end{array}$ & $\begin{array}{c}\text { Butyrate } \\
\mathrm{g}^{-\mathrm{kg}^{-1}}\end{array}$ \\
\hline Soybean meal & 424 & 424 \\
Fish meal & 232 & 232 \\
Wheat flour & 150 & 150 \\
Kaolin & 84 & 64 \\
Soy lecithin & 30 & 30 \\
Monocalcium phosphate & 20 & 20 \\
Mineral-vitamin premix & 15 & 15 \\
Sodium chloride & 12 & 12 \\
Soybean oil & 10 & 10 \\
Fish oil & 10 & 10 \\
Magnesium sulphate & 7.7 & 7.7 \\
Binder (CMC) & 5.0 & 5.0 \\
Vitamin C & 0.6 & 0.6 \\
Sodium butyrate & 0 & 20 \\
\hline
\end{tabular}

CMC - carboxymethyl cellulose.

${ }^{1}$ Probiotic was added after diet preparation (Vieira et al., 2008).

Table 2 - Proximate composition (dry matter) of the diets used in the growth of Litopenaeus vannamei in clearwater system

\begin{tabular}{lcccc}
\hline Nutrient & Control & Butyrate & Probiotic & $\begin{array}{c}\text { Butyrate }+ \\
\text { probiotic }\end{array}$ \\
\hline Humidity (\%) & 10.81 & 9.79 & 10.6 & 10.12 \\
Gross protein (\%) & 39.51 & 40.08 & 41.54 & 42.01 \\
Ether extract (\%) & 8.89 & 8.66 & 8.51 & 8.54 \\
Acid detergent fiber (\%) & 6.25 & 4.61 & 4.13 & 5.45 \\
Ash (\%) & 21.72 & 20.64 & 21.76 & 20.91 \\
\hline
\end{tabular}


and the animal replaced with another acclimated specimen. The percentages of positive choices for each tested diet relative to all other diets were calculated according to the following expression: positive choices $(\%)=($ total number of choices/total number of comparisons) $\times 100$.

Shrimps (mean weight of $5.28 \pm 0.08 \mathrm{~g}$ ) were stocked in 16 tanks of $800 \mathrm{~L}$ (inside a greenhouse) at a density of 40 shrimp $\mathrm{m}^{-3}$ in clearwater system with $30 \%$ of static water exchange per day. The experiment lasted four weeks between the months of April and May 2015. Animals were fed diets in a quantity equivalent to $6 \%$ of biomass divided into four times a day $(8: 00,12: 00,14: 00$, and 17:00 h). The feeding was adjusted according to weight checks conducted weekly. All treatments were performed in quadruplicate.

Temperature and dissolved oxygen were measured daily (YSI model Pro 20) and salinity was maintained at 30 ppt. Water $\mathrm{pH}$, ammonia, and nitrite were also measured once a week.

After four weeks, all shrimps were counted and weighted to evaluate weight gain, feed conversion, and survival using the follow equations:

$$
\begin{gathered}
\text { Weekly weight gain }=\frac{\text { Final weight }(\mathrm{g})-\text { Initial weight }(\mathrm{g})}{\text { Weeks }} \\
\text { Feed conversion }=\frac{\text { Feed intake }(\mathrm{g})}{\text { Final biomass }(\mathrm{g})} \\
\text { Survival rate }=\frac{\text { No. survive shrimps }}{\text { Total number stock }} \times 100
\end{gathered}
$$

Five shrimps from each experimental unit were sampled to form a pool per unit for microbiology analyses. The midguts of the shrimps were excised with forceps and scalpel and then homogenized in sterile saline solution in $3 \% \mathrm{NaCl}$ in a grail. The samples were then serially diluted (1/10) and seeded in Agar Marine culture medium for total heterotrophic marine bacteria and Agar TCBS (Thiosulphate Citrate Bile Sucrose), which is a selective medium for vibrios. Finally, they were incubated at $29^{\circ} \mathrm{C}$ for $24 \mathrm{~h}$.

Haemolymph from 10 shrimps per experimental unit was collected to form two pools. The samples were collected with $1 \mathrm{~mL}$ sterile syringes with a $21 \mathrm{G}$ needle and cooled at $4{ }^{\circ} \mathrm{C}$. A total of $40 \mu \mathrm{L}$ hemolymph from each animal were fixed in solution of $4 \%$ formaldehyde/MAS (sodium citrate $27 \mathrm{mM}$, EDTA $9 \mathrm{mM}$, glucose $115 \mathrm{mM}$, $\mathrm{NaCl} 336 \mathrm{mM}, \mathrm{pH}$ 7.0) for total haemocyte count (THC). The remaining hemolymph was left to clot at $4{ }^{\circ} \mathrm{C}$. The coagulated haemolymph was frozen at $-20{ }^{\circ} \mathrm{C}$ and repeatedly centrifuged at $10,000 \mathrm{~g}$ for $10 \mathrm{~min}$ to obtain the serum, which was aliquoted and stored at $-20{ }^{\circ} \mathrm{C}$ for later use in other immunological analyses.
The number of haemocytes per millilitre of haemolymph was estimated by direct counting in a Neubauer chamber, considering dilution.

To determine serum agglutination titre, serum samples of $50 \mu \mathrm{L}$ were serially diluted in TBS-1 $(50 \mathrm{mM}$ Tris, $150 \mathrm{mM} \mathrm{NaCl}, 10 \mathrm{mM} \mathrm{CaCl}, 5 \mathrm{~m} \mathrm{M} \mathrm{MgCl}, \mathrm{pH}$ 7.4) in a flat-bottomed 96-microwell plate. After adding $50 \mu \mathrm{L}$ of $2 \%$ solution from dog erythrocytes in TBS- 1 solution, the microplate was incubated for $3 \mathrm{~h}$ at $25{ }^{\circ} \mathrm{C}$ in a humidified chamber. The control was performed through the substitution of serum by TBS. Serum agglutination titre was defined as the reciprocal of the highest dilution capable of agglutinating erythrocytes.

Phenoloxidase activity (PO) was determined by spectrophotometry (DO490 nm) through the formation of DOPA-chrome pigment after oxidation of the substrate L-dihydroxyphenylalanine (L-DOPA, Sigma Chemical Co., St. Louis, MO, USA), using the methodology described by Söderhäll and Häll (1984). Briefly, serum samples were diluted (1:8) in TBS-2 (10 mM Tris, $336 \mathrm{mM}$ $\mathrm{NaCl}, 5 \mathrm{mM} \mathrm{CaCl}_{2}, 10 \mathrm{mM} \mathrm{MgCl}, \mathrm{pH} \mathrm{7.6)}$ and $50 \mu \mathrm{L}$ of this solution were preincubated with an equal volume of the enzyme inducer trypsin (SIGMA, $1 \mathrm{mg} \mathrm{mL}^{-1}$ ) for $15 \mathrm{~min}$ at $20{ }^{\circ} \mathrm{C}$ in a flat-bottomed 96 -microwell plate. In controls, trypsin and serum were replaced by TBS-2. After incubation, $50 \mu \mathrm{L}$ of L-DOPA $\left(3 \mathrm{mg} \mathrm{mL}^{-1}\right)$ were added to the wells and the formation of DOPA-chrome was monitored after $0,5,10$, and $15 \mathrm{~min}$. One unit of the specific activity from $\mathrm{PO}$ was equivalent to the variation of 0.001 in the absorbance. $\mathrm{min}^{-1} \mathrm{mg}^{-1}$ of protein.

The concentration of protein in the haemolymph was estimated by the method of Bradford (1976) through the use of bovine serum-albumin as standard.

At harvest, 10 shrimps (in the intermolt stage) from each tank were transferred to 1630 -L aquaria with aeration $\left(\mathrm{O}_{2}>5 \mathrm{mg} \mathrm{L}{ }^{-1}\right)$ and heating systems $\left(29 \pm 1{ }^{\circ} \mathrm{C}\right)$. Each shrimp was injected with $100 \mu \mathrm{L}$ of $V$. alginolyticus at a concentration of $1 \times 10^{7} \mathrm{cfu} \mathrm{mL}^{-1}$, according to the $\mathrm{LD}_{50}$ test conducted previously by the authors (data not shown). As a control group, a sampling of shrimps was injected with $100 \mathrm{uL}$ of sterile saline solution. The shrimps were monitored during $48 \mathrm{~h}$ and after this period, they were evaluated for survival and immunological parameters. All treatments were performed in quadruplicate.

Before being subjected to statistical analysis, the bacteriological count data were transformed into $\log 10(x+1)$ and the serum agglutination data were transformed into $\log 2(x+1)$. Data homoscedasticity was assessed by the test of Bartlett. After verifying the assumptions of normality 
and homoscedasticity, data were subjected to unifactorial analysis of variance supplemented by the Tukey test of separation of averages, both at the significance level of 5\%. Attractiveness was analyzed by using the non-parametric chi-square. Differences in survival levels between treatments were analyzed by Kaplan-Meier log-rank $\chi^{2}$ tests.

\section{Results}

Diet supplemented with butyrate had higher attractiveness, but only when compared with control diet (Table 3). The other diets showed no significant differences when compared among themselves.

Water quality parameters remained within acceptable standards for marine shrimp (Boyd and Gautier, 2000) without great temperature $(29.56 \pm 0.30)$, oxygen (6.07 \pm 0.05$), \mathrm{pH}(8.37 \pm 0.08)$, ammonia $(0.55 \pm 0.19)$, or nitrite $(0.13 \pm 0.11)$ variations. After four weeks, shrimps of the different treatments showed no significant differences in performance parameters (Table 4).

Vibrio spp. and total heterotrophic bacteria counts in the midgut revealed no differences among treatments (Table 5) when compared with the control group, while the lactic acid bacteria count was higher in diets supplemented with the probiotic $(\mathrm{P}<0.05)$.

At the end of the experiment and before challenge, serum agglutination titre did not differ among the treatments (Table 6). Total haemocyte count was, however, higher in the butyrate treatment when compared with probiotic and butyrate + probiotic treatment, but did not differ with the control group. Phenoloxidase activity was significantly higher in the probiotic treatments compared with the other treatments.

Table 3 - Frequency of positive choices (\%) of shrimp Litopenaeus vannamei kept in the Y-maze and fed different diets

\begin{tabular}{lcccc}
\hline Diet & Control & Butyrate & Probiotic & $\begin{array}{c}\text { Butyrate }+ \\
\text { probiotic }\end{array}$ \\
\hline Control & - & $80 *$ & 60 & 40 \\
Butyrate & 20 & - & 40 & 50 \\
Probiotic & 40 & 60 & - & 50 \\
Butyrate + probiotic & 60 & 50 & 50 & - \\
\hline
\end{tabular}

* Difference in chi-square test $(\mathrm{P}<0.05)$.
After challenge, THC decreased significantly $(\mathrm{P}<0.003)$, but only in the butyrate treatment, compared with THC before infection. Also, the butyrate treatment had a lower THC when compared with the butyrate + probiotic treatment, but without showing differences with the other treatments. The control group had no differences in number of haemocytes when compared with the other treatments. Additionally, while the agglutination titre increased significantly in all treatments after infection $(\mathrm{P}<0.0001)$, the control group presented no differences compared with other treatments. There were differences only between the probiotic and butyrate + probiotic treatment, with a higher agglutination titre in the probiotic group. No significant differences were noted in PO activity among the treatments; however, enzymatic activity was numerically lower in the control group.

Fourteen hours after challenge, shrimps started to present symptoms of lethargy and necrosis in the tissues, followed by the first deaths. After $48 \mathrm{~h}$, survival was significantly higher in the treatments compared with the control group (Figure 1). However, the results obtained from the use of probiotic combined with organic salt did not significantly differ from the use in isolation.

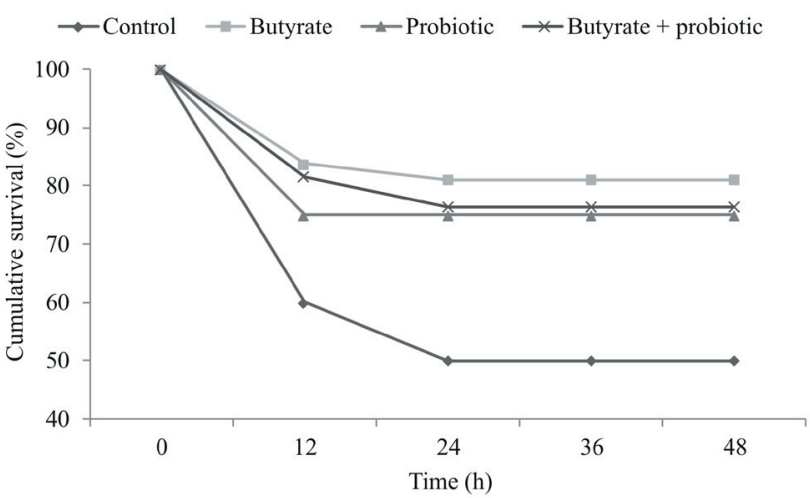

Treatments (butyrate, probiotic, and butyrate + probiotic) with significant difference $(\mathrm{P}<0.05)$ to control group by Kaplan-Meyer log-rank $\chi^{2}$ test.

Figure 1 - Cumulative survival of $L$. vannamei fed different diets (butyrate $2 \%$, probiotic, butyrate $2 \%+$ probiotic, and control) after challenge with $V$. alginolyticus.

Table 4 - Performance parameters of Litopenaeus vannamei cultivated in clearwater system and fed different diets

\begin{tabular}{lccccc}
\hline Diet & Initial weight $(\mathrm{g})$ & Final weight $(\mathrm{g})$ & Weekly weight gain $(\mathrm{g})$ & Feed conversion & Survival $(\%)$ \\
\hline Control & $5.34 \pm 0.19$ & $12.58 \pm 0.31$ & $1.84 \pm 0.36$ & $1.9 \pm 0.16$ & $96.7 \pm 0.8$ \\
Butyrate & $5.17 \pm 0.20$ & $12.11 \pm 0.36$ & $1.74 \pm 0.29$ & $2.2 \pm 0.21$ & $98.3 \pm 0.6$ \\
Probiotic & $5.32 \pm 0.21$ & $12.22 \pm 0.58$ & $1.73 \pm 0.40$ & $2.3 \pm 0.28$ & $97.5 \pm 0.5$ \\
Butyrate + probiotic & $5.28 \pm 0.22$ & $12.35 \pm 0.55$ & $1.77 \pm 0.21$ & $2.0 \pm 0.09$ & $97.5 \pm 1.0$ \\
\hline
\end{tabular}


Table 5 - Microbiological count $(\log )$ of the intestine of Litopenaeus vannamei fed different diets after four weeks of cultivation

\begin{tabular}{lccc}
\hline Treatment & Vibrio sp. & $\begin{array}{c}\text { Total heterotrophic } \\
\text { bacteria }\end{array}$ & $\begin{array}{c}\text { Lactic acid } \\
\text { bacteria }\end{array}$ \\
\hline Control & $6.56 \pm 0.98 \mathrm{a}$ & $8.54 \pm 1.31 \mathrm{a}$ & $0.79 \pm 1.58 \mathrm{a}$ \\
Butyrate & $7.59 \pm 0.97 \mathrm{a}$ & $8.54 \pm 0.25 \mathrm{a}$ & $0.67 \pm 1.35 \mathrm{a}$ \\
Probiotic & $6.97 \pm 0.79 \mathrm{a}$ & $8.33 \pm 0.41 \mathrm{a}$ & $3.54 \pm 0.71 \mathrm{~b}$ \\
Butyrate + probiotic & $7.03 \pm 0.51 \mathrm{a}$ & $8.49 \pm 0.42 \mathrm{a}$ & $3.55 \pm 0.65 \mathrm{~b}$ \\
\hline
\end{tabular}

Table 6 - Total haemocyte count (THC), phenoloxidase activity (PO), and serum agglutination titre of Litopenaeus vannamei shrimp before and after challenge with Vibrio alginolyticus

\begin{tabular}{lccc}
\hline Treatment & $\begin{array}{c}\text { THC } \\
\left(\times 10^{6} \mathrm{~mL}^{-1}\right)\end{array}$ & $\begin{array}{c}\text { PO activity } \\
\left(\mathrm{U} \mathrm{mg}^{-1} \mathrm{~min}^{-1}\right)\end{array}$ & $\begin{array}{c}\text { Agglutination } \\
\text { titer }\end{array}$ \\
\hline \multicolumn{4}{c}{ Before infection } \\
Control & $44.3 \pm 6.3 \mathrm{Aab}$ & $27.17 \pm 8.54 \mathrm{Ab}$ & $10.83 \pm 0.50 \mathrm{~A}$ \\
Butyrate & $58.57 \pm 6.7 \mathrm{Ab}$ & $17.51 \pm 4.45 \mathrm{Aab}$ & $10.58 \pm 0.00 \mathrm{~A}$ \\
Probiotic & $29.33 \pm 7.9 \mathrm{Aa}$ & $42.38 \pm 3.93 \mathrm{Ac}$ & $11.33 \pm 0.50 \mathrm{~A}$ \\
Butyrate + probiotic & $39.1 \pm 8.5 \mathrm{Aa}$ & $14.20 \pm 1.96 \mathrm{Aa}$ & $11.33 \pm 0.50 \mathrm{~A}$ \\
\multicolumn{4}{c}{$\mathrm{After}$ infection } \\
Control & $33.30 \pm 7.61 \mathrm{Aab}$ & $27.17 \pm 3.11 \mathrm{~A}$ & $14.08 \pm 0.58 \mathrm{Bab}$ \\
Butyrate & $26.32 \pm 3.92 \mathrm{Ba}$ & $43.87 \pm 6.15 \mathrm{~B}$ & $13.83 \pm 0.50 \mathrm{Bab}$ \\
Probiotic & $32.21 \pm 1.25 \mathrm{Aab}$ & $33.12 \pm 2.48 \mathrm{~B}$ & $14.83 \pm 0.50 \mathrm{Bb}$ \\
Butyrate + probiotic & $45.05 \pm 3.51 \mathrm{Ab}$ & $48.12 \pm 17.60 \mathrm{~B}$ & $13.33 \pm 0.50 \mathrm{Ba}$ \\
\hline
\end{tabular}

Uppercase letters indicate significant differences in time; lowercase letters indicate statistical differences among the treatments.

\section{Discussion}

The use of additives in diets, including organic acids, or their salts, can change palatability, either decreasing or increasing attractiveness. Silva et al. (2013) found that the attractiveness and the intake of commercial diets for shrimp increased when supplemented with sodium butyrate and propionate. In another study, it was observed that citric and lactic acids also increased attractiveness of diets for tilapia (Oreochromis niloticus). However, acetic acid and metacetonic acid had the opposite effect, resulting in the rejection (Xie et al., 2003). In the present study, the only diet presenting differences in attractiveness was the one supplemented with butyrate when compared with the control diet, which was the least attractive diet to shrimps. The other diets showed no differences among them, indicating that the additives did not decrease the attractiveness of feed.

Several studies have reported that organic acids complemented by probiotics can improve performance parameters through the increased activity of digestive enzymes (Wang, 2007; Zhou et al., 2009), improving the digestion of macro and micro nutrients (Lin et al., 2004; Hossain et al., 2007) and the digestibility of protein (Lückstädt, 2008; Buglione-Neto et al., 2013), consequently improving feed conversion and specific growth rate (Kongnum and Hongpattarakere, 2012; Romano et al., 2015). Litopenaeus vannamei shrimp fed both organic salts, such as propionate and sodium butyrate, and the probiotic L. plantarum had higher final weight, feed efficiency, and survival when compared with the control group (Kongnum and Hongpattarakere, 2012; Silva et al., 2014). In the present study, we did not observe the same behavior, possibly as a result of rearing conditions, since shrimps were not exposed to any stress in our clearwater system with low density and good water quality, providing ideal growth conditions.

Shrimps receiving the probiotic showed higher LAB colony counts in the intestine compared with groups not receiving the probiotic, proving that $L$. plantarum could remain in the feed and reach the intestine through the ingestion of feed. Similar studies with $L$. vannamei supplemented with $L$. plantarum have also shown that the intestinal microbiota is modified by increasing the concentration of LAB and, consequently, decreasing the concentrations of Vibrio spp. (Vieira et al., 2010). A study on L. stylirostris reported that the lactic acid bacterium Pediococcus acidilactici could also change the microbiota of shrimp and, as a result, decrease the concentrations of Vibrio spp. and total heterotrophic bacteria in the intestine (Castex et al., 2008).

Even though differences in Vibrio spp. or total heterotrophic bacteria counts were not observed among treatments in a previous study, LAB could still inhibit the growth of different microorganisms by decreasing the $\mathrm{pH}$ of their environment, increasing competition for nutrients and sites of adhesion, as well as producing antimicrobial compounds (Gatesoupe, 2008). On the other hand, in addition to decreasing $\mathrm{pH}$, organic acids, or their salts, can produce chelate complexes with minerals, thus inhibiting the growth of bacteria, such as those of the genus Vibrio (Whitaker et al., 2010). In L. vannamei, studies have shown that organic salts decrease the concentration of Vibrio spp. in both hepatopancreas and intestine (Silva et al., 2013, 2014; Romano et al., 2015).

In the experimental challenge with $V$. alginolyticus, shrimps fed diets supplemented with sodium butyrate and/or the probiotic had higher survival than shrimps from the control group $(\mathrm{P}<0.019)$. Lactobacillus plantarum also has proven to be beneficial for L. vannamei by increasing humoral and cellular immune response after challenge with $V$. alginolyticus (Chiu et al., 2007) and increasing the survival after infection with $V$. harveyi (Vieira et al. 2007, 2010). Organic salts also increase the survival of shrimps after challenges with $V$. harveyi (Roman et al., 2015) and the survival of tilapia fed $0.5 \%$ potassium diformiate 
(KDF) after challenge with Vibrio anguillarum (Ramli et al., 2005). Diets with $0.3 \% \mathrm{KDF}$ also help to decrease overall mortality in tilapia challenged with Streptococcus agalactiae ( $\mathrm{Ng}$ et al., 2009). However, we suggest further studies using oral/bath infection, emulating the natural infection route and minimizing possible septicemia caused by direct injection into the animal aiming at obtaining the real benefits of probiotic/organic acid to the gut.

One of the most important determinants of host immunological response in shrimp is PO activity. The results showed that before infection, $\mathrm{PO}$ activity was higher in the probiotic treatment when compared with all treatments. However, the supplementation with butyrate seemed to neutralize the effect of the probiotic on the PO activity in the treatment using both feed additives. After infection, even though we did not obtain statistical differences, the numerically higher PO activity in shrimp fed diets supplemented with additives (butyrate, probiotic, and butyrate + probiotic) may have helped to enhance host resistance to $V$. alginolyticus challenge.

Shrimp fed probiotic diets (probiotic and butyrate + probiotic) before infection and shrimp fed butyrate diet after infection had lower THC. However, the TCH in these treatments was close to $30 \times 10^{6}$ cells $\mathrm{mL}^{-1}$, common value for healthy shrimp (Rodríguez and Le Moullac, 2000). In addition, this lower THC did not seem to be prejudicial, once the survival in these treatments (probiotic, butyrate, and probiotic + butyrate) after $V$. alginolyticus challenge was higher than control.

The lower agglutinating titer in shrimps fed diet supplemented with both additives (butyrate + probiotics), although significantly different, does not seem to be biologically important, once the numerical difference is small.

However, in this experiment, the results of the use of probiotic combined with organic salt did not differ significantly from its use in isolation, contrasting with the results obtained in broiler chickens fed organic acids combined with probiotics, presenting better results than individual treatments after infection with Salmonella enteritidis (Wolfenden et al., 2007).

\section{Conclusions}

Sodium butyrate and $L$. plantarum increase the resistance of $L$. vannamei to challenge with $V$. alginolyticus; however, it does not change the performance or the immunological parameters of shrimp reared in the clearwater system. Adding the probiotic L. plantarum to the diet increases LAB counts in the intestine of L. vannamei; however, it does not change Vibrio spp. or total heterotrophic bacteria counts in the midgut. Finally, the use of $L$. plantarum and sodium butyrate in feed does not alter its attractiveness.

\section{Acknowledgments}

The authors acknowledge the financial support of the Conselho Nacional de Desenvolvimento Científico e Tecnológico (CNPq/475906/2012-8) and Coordenação de Aperfeiçoamento de Pessoal de Nível Superior (CAPES PEC-PG). Felipe Vieira and Walter Seiffert received productivity research fellowships from $\mathrm{CNPq}$ (protocol: PQ 309868/2014-9 and 302792/2012-0 respectively). The authors acknowledge Labnutri, specially Dr. Débora Fracalossi, for the preparation of diets, and Nicoluzzi, for providing the ingredients used in the diets.

\section{References}

AOAC - Association of Official Analytical Chemists. 2005. Official methods of analysis of the Association of Analytical Chemists International. 18th ed. Gathersburg, MD, U.S.A.

Boyd, C. E. and Gautier, D. 2000. Effluent composition and water quality standards. Global Aquaculture Advocate 3:61-66.

Bradford, M. M. 1976. A rapid and sensitive method for the quantitation of microgram quantities of protein utilizing the principle of protein-dye binding. Analytical Biochemistry 72:248-254.

Buglione-Neto, C.; Mouriño, J. L.; Vieira, F. N.; Silva, B. C.; Jatobá, A.; Seiffert, W.; Fracalossi, D. M. and Andreatta, E. 2013. Métodos para determinação da digestibilidade aparente de dietas para camarão marinho suplementadas com probiótico. Pesquisa Agropecuária Brasileira 48:1021-1027.

Castex, M.; Chim, L.; Pham, D.; Lemaire, P.; Wabete, N.; Nicolas, J.-L.; Schmidely, P. and Mariojouls, C. 2008. Probiotic P. acidilactici application in shrimp Litopenaeus stylirostris culture subject to vibriosis in New Caledonia. Aquaculture 275:182-193.

Chiu, C. H.; Guu, Y. K.; Liu, C. H.; Pan, T. M. and Cheng, W. 2007. Immune responses and gene expression in white shrimp, Litopenaeus vannamei, induced by Lactobacillus plantarum. Fish \& Shellfish Immunology 23:364-377.

Costanzo, D.; Murby, J. and Bates, J. 2005. Ecosystem response to antibiotics entering the aquatic environment. Marine Pollution Bulletin 51:218-223.

Defoirdt, T.; Sorgeloos, P. and Bossier, P. 2011. Alternatives to antibiotics for the control of bacterial disease in aquaculture. Current Opinion in Microbiology 14:251-258.

FAO - Food and Agriculture Organization of the United Nations 2012. The State of World Fisheries and Aquaculture. SOFIA, Rome. 209p.

Gatesoupe, F. J. 2008. Updating the importance of lactic acid bacteria in fish farming: natural occurrence and probiotic treatments. Journal of Molecular Microbiology and Biotechnology 14:107-114.

Gram, L.; Melchiorsen, J.; Spanggaard, B.; Huber, I. and Nielsen, T. F. 1999. Inhibition of Vibrio anguillarum by Pseudomonas fluorescens AH2, a possible probiotic treatment of fish. Applied and Environmental Microbiology 65:969-973.

Hossain, M. A.; Pandey, A. and Satoh, S. 2007. Effects of organic acids on growth and phosphorus utilization in red sea bream Pagrus major. Fisheries Science 73:1309-1317. 
Jones, D. L. 1998. Organic acids in the rhizosphere-a critical review. Plant and Soil 205:25-44.

Kongnum, K. and Hongpattarakere, T. 2012. Effect of Lactobacillus plantarum isolated from digestive tract of wild shrimp on growth and survival of white shrimp (Litopenaeus vannamei) challenged with Vibrio harveyi. Fish \& Shellfish Immunology 32:170-177.

Lafferty, K. D.; Harvell, C. D.; Conrad, J. M.; Friedman, C. S.; Kent, M. L.; Kuris, A. M.; Powell, E. N.; Rondeau, D. and Saksida, S. M. 2015. Infectious diseases affect marine fisheries and aquaculture economics. Annual Review of Marine Science 7:471-496.

Lightner, D. V. 2011. Virus diseases of farmed shrimp in the Western Hemisphere (the Americas): a review. Journal of Invertebrate Pathology 106:110-130.

Lightner, D. V.; Redman, R. M.; Pantoja, C. R.; Tang, K. F. Noble, B. L. Schofield, P.; Mohney, L. L.; Nunan, L. M. and Navarro, S. A. 2012. Historic emergence, impact and current status of shrimp pathogens in the Americas. Journal of Invertebrate Pathology 110:174-183

Lin, H. Z.; Guo, Z.; Yang, Y.; Zheng, W. and Li, Z. J. 2004. Effect of dietary probiotics on apparent digestibility coefficients of nutrients of white shrimp Litopenaeus vannamei Boone. Aquaculture Research 35:1441-1447.

Lückstädt, C. 2008. The use of acidifiers in fish nutrition. CAB Reviews: Perspectives in Agriculture, Veterinary Science, Nutrition and Natural Resources 3:1-8.

Ng, W.-K.; Koh, C.-B.; Sudesh, K. and Siti-Zahrah, A. 2009. Organic acids potential replacement for antibiotic treatments of tilapia. Global Aquaculture Advocate 5:93-94.

Nunes, A. J. P.; Sá, M. V. C.; Andriola-Neto, F. F. and Lemos, D. 2006. Behavioral response to selected feed attractants and stimulants in Pacific white shrimp, Litopenaeus vannamei. Aquaculture 260:244-254.

Partanen, K. H. and Mroz, Z. 1999. Organic acids for performance enhancement in pig diets. Nutrition Research Reviews 12:117-145.

Ramli, N.; Heindl, U. and Sunanto, S. 2005. Effect of potassiumdiformate on growth performance of tilapia challenged with Vibrio anguillarum. World Aquaculture Society 9-13.

Rodríguez, J. and Le Moullac, G. 2000. State of the art of immunological tools and health control of penaeid shrimp. Aquaculture 191:109-119.

Romano,N.;Koh,C.-B.andNg,W.-K.2015.Dietarymicroencapsulated organic acids blend enhances growth, phosphorus utilization, immune response, hepatopancreatic integrity and resistance against Vibrio harveyi in white shrimp, Litopenaeus vannamei. Aquaculture 435:228-236.

Silva, B. C.; Vieira, F. N.; Mouriño, J. L. P.; Ferreira, G. S. and Seiffert, W. Q. 2013. Salts of organic acids selection by multiple characteristics for marine shrimp nutrition. Aquaculture 384:104-110.
Silva, B. C.; Vieira, F. N.; Mouriño, J. L. P.; Bolivar, N. and Seiffert, W. Q. 2014. Butyrate and propionate improve the growth performance of Litopenaeus vannamei. Aquaculture Research 47:612-623.

Söderhäll, K. and Häll, L. 1984. Lipopolysaccharide-induced activation of prophenoloxidase activating system in crayfish haemocyte lysate. Biochimica et Biophysica Acta (BBA)-General Subjects 797:99-104.

Tran, L.; Nunan, L.; Redman, R. M.; Mohney, L. L.; Pantoja, C. R.; Fitzsimmons, K. and Lightner, D. V. 2013. Determination of the infectious nature of the agent of acute hepatopancreatic necrosis syndrome affecting penaeid shrimp. Diseases of Aquatic Organisms 105:e55.

Vieira, F. N.; Buglione Neto, C.C.; Mouriño, J. L. P.; Jatobá, A.; Ramirez, C.; Martins, M. L.; Barracco, M. A. A. M. and Vinatea, L. A. 2008. Time-related action of Lactobacillus plantarum in the bacterial microbiota of shrimp digestive tract and its action as immunostimulant. Pesquisa Agropecuária Brasileira 43:763-769.

Vieira, F. N.; Jatobá, A.; Mouriño, J. L. P.; Vieira, E. A.; Soares, M.; Silva, B. C.; Seiffert, W. Q.; Martins, M. L. and Vinatea, L. A. 2013. In vitro selection of bacteria with potential for use as probiotics in marine shrimp culture. Pesquisa Agropecuária Brasileira 48:998-1004.

Vieira, F. N.; Pedrotti, F. S.; Buglione Neto, C. C.; Mouriño, J. L. P.; Beltrame, E.; Martins, M. L.; Ramirez, C. and Arana, L. A. V. 2007. Lactic-acid bacteria increase the survival of marine shrimp, Litopenaeus vannamei, after infection with Vibrio harveyi. Brazilian Journal of Oceanography 55:251-255.

Vieira, F. N.; Buglione, C. C.; Mouriño, J. P. L.; Jatobá, A.; Martins, M. L.; Schleder, D. D.; Andreatta, E. R.; Barraco, M. A. and Vinatea, L. A. 2010. Effect of probiotic supplemented diet on marine shrimp survival after challenge with Vibrio harveyi. Arquivo Brasileiro de Medicina Veterinária e Zootecnia 62:631-638.

Wang, Y.-B. 2007. Effect of probiotics on growth performance and digestive enzyme activity of the shrimp Penaeus vannamei. Aquaculture 269:259-264.

Whitaker, W. B.; Parent, M. A.; Naughton, L. M.; Richards, G. P.; Blumerman, S. L. and Boyd, E. F. 2010. Modulation of responses of Vibrio parahaemolyticus O3: $\mathrm{K} 6$ to $\mathrm{pH}$ and temperature stresses by growth at different salt concentrations. Applied and Environmental Microbiology 76:4720-4729.

Wolfenden, A.; Vicente, J.; Higgins, J.; Andreatti Filho, R.; Higgins, S.; Hargis, B. and Tellez, G. 2007. Effect of organic acids and probiotics on Salmonella enteritidis infection in broiler chickens. International Journal of Poultry Science 6:403-405.

Xie, S.; Zhang, L. and Wang, D. 2003. Effects of several organic acids on the feeding behavior of Tilapia nilotica. Journal of Applied Ichthyology 19:255-257.

Zhou, X.-x.; Wang, Y.-b. and Li, W.-f. 2009. Effect of probiotic on larvae shrimp (Penaeus vannamei) based on water quality, survival rate and digestive enzyme activities. Aquaculture 287:349-353. 